\title{
Variation in black spruce (Picea mariana (Mill.) BSP) wood quality after thinning
}

\author{
Manon Vincent • Cornelia Krause • Ahmed Koubaa
}

Received: 8 August 2010 / Accepted: 16 March 2011 /Published online: 30 August 2011

(C) INRA and Springer Science+Business Media B.V. 2011

\begin{abstract}
- Introduction Commercial thinning (CT) could contribute to increase short-term tree growth and be beneficial in a cold climate, as in boreal regions. Thus, growth rate, ring density and flexural modulus of elasticity (MOE) of trees may change after CT. Moreover, mechanical wood properties vary with position in the tree, and there is a need to develop optimal log allocation strategies in order to allocate logs to their best use.

- Objectives The objectives of the study were to evaluate the impact of commercial thinning on the lumber quality of nine thinned stands compared with unthinned stands and to determine whether this impact varies longitudinally along the first $4 \mathrm{~m}$ of the stem.

- Results Despite a significant increase in ring width following thinning $(p=0.0003)$, annual variations in ring density were subtle. No significant variation in average ring
\end{abstract}

Handling Editor: Barry Gardiner

M. Vincent $(\bowtie) \cdot$ C. Krause

Département des Sciences Fondamentales,

Université du Québec à Chicoutimi,

Pavillon Principal, 555 Boulevard de l'Université,

Chicoutimi, Québec, Canada G7H 2B1

e-mail: manon_vincent@uqac.ca

C. Krause

e-mail: ckrause@uqac.ca

\section{A. Koubaa}

Département des Sciences Appliquées,

Université du Québec en Abitibi-Témiscaminque,

Campus Rouyn-Noranda, 445 Boulevard de l'Université,

Rouyn-Noranda, Québec, Canada J9X 5E4

e-mail: ahmed.koubaa@uqat.ca density due to CT was observed ( $p=0.5122)$ after thinning, which may be explained by between-stand variability. Thinning showed no significant effect on flexural MOE over a 10 -year period. Moreover, variability in average ring density along the stem with tree height was greater than that induced by thinning. A significant decrease in ring density was observed up the stem (from 490 to $463 \mathrm{~kg} \mathrm{~m}^{-3}$ up to the fourth metre, $p<0.0001$ ).

- Conclusion Because it induced increased growth without negative effects on wood mechanical properties, thinning is advisable for slow growth naturally regenerated black spruce stands in the northern boreal region.

Keywords Black spruce $\cdot$ Modulus of elasticity $\cdot$ Ring density. Wood quality. Commercial thinning

\section{Introduction}

The boreal forest biome covers much of the landmass of the northern hemisphere and contains most of the global carbon stock (Melillo et al. 1993; Dixon et al. 1994). Black spruce (Picea mariana (Mill.) BSP.) is one of the most widespread boreal tree species in Canada (Parent and Fortin 2008; Zhang and Koubaa 2009). Its excellent wood and fibre quality makes it highly valued for pulpwood and lumber production (Zhang and Koubaa 2009). However, black spruce stems are relatively small in diameter, especially in northern areas, resulting in very low lumber volume recovery per stem volume (Pnevmaticos et al. 1979). Increased light penetration to the forest floor after commercial thinning can raise the temperature of surface soil layers, thereby accelerating nitrogen mineralization (Thibodeau et al. 2000) and increasing the available light to individual trees. This can contribute to increase short- 
term tree growth and can be particularly beneficial in a cold climate, as in boreal regions (Pothier 2002). Partial cutting through thinning could therefore be a sound choice for sustainable development within global market constraints whilst achieving maximum economic value (Zhang et al. 2006).

Many studies have reported that commercial thinning (CT) regularized forest size and growth, increased sawn timber availability, decreased rotation age and management costs, and enhanced stand value and quality (Prégent 1998; Cameron 2002; Petrás 2002). However, forest product properties also depend strongly on wood characteristics such as ring density, basic density, modulus of elasticity (MOE) and microfibril angle (Downes et al. 2002; Zhang et al. 2005). More specifically, wood density has a major impact on the yield, quality and value of wood-based composites and solid wood products (Shi et al. 2007). Both microfibril angle and intra-ring wood density variation determine a wood's suitability for specific end uses (Echols 1972; Koubaa et al. 2002). Numerous studies have investigated the relationship between growth rate and wood quality in many commercial species, with somewhat inconsistent results (Kellogg and Warren 1984; Castéra et al. 1996; Zhang et al. 2002). Moreover, whereas many studies have evaluated the impact of initial spacing on the wood value recovery chain (Koga and Zhang 2002; Zhang et al. 2002; Alteyrac et al. 2005), to our knowledge, none have addressed variations in wood mechanical properties after commercial thinning in natural black spruce stands. Nevertheless, black spruce is one of the main species used in machine stress-rated (MSR) lumber production, and MOE is one of the most important lumber bending properties used to determine end uses and MSR grade yield.

Because mechanical wood properties vary with position in the tree (Larson et al. 2004; Alteyrac et al. 2005), there is an increasing need to develop optimal $\log$ allocation strategies in order to allocate logs to their best use, maximize the value of the resource and ensure end-product quality (Shi et al. 2007). According to some authors, however, research on the effect of silvicultural practices on the value recovery chain has lagged behind research on growth and yield. The result is a disconnection across the value-added chain as the forest industry still lacks some basic information linking tree growth to product value (Briggs and Fight 1992; Kang et al. 2004).

This study tested the hypothesis that thinning treatments are followed by changes in the flexural MOE and density of black spruce wood. The objectives were to evaluate the impact of commercial thinning on the lumber quality of nine thinned stands compared with unthinned strands and to determine whether this impact varies longitudinally along the first $4 \mathrm{~m}$ of the stem.

\section{Materials and methods}

\subsection{Study area}

Wood from nine thinned stands and six control stands in the boreal forest of Quebec, Canada, were investigated. Stands had to be accessible by truck and located close to trails so that field material and samples could be transported by foot. Stands were selected according to two main criteria: thinning treatment was performed 10-12 years before sampling and thinning was performed in naturally regenerated unmanaged natural black spruce stands (Table 1). Whenever possible, a nearby unthinned natural black spruce stand with similar characteristics was selected as a control (Table 1). Control stands were selected mainly for stand age and location close to a thinned stand. In two instances where all stands had the same environmental characteristics, the same control stand was used for comparison with more than one nearby thinned stand. To identify the stands, initial letters refer to the stand location followed by a number representing the thinning year or the letter C for control (Table 1). See also Vincent et al. (2009a, b) for further information.

Latitude ranged from $47.9^{\circ} \mathrm{N}$ to $49^{\circ} \mathrm{N}$, longitude from $70.5^{\circ} \mathrm{W}$ to $72.7^{\circ} \mathrm{W}$ and altitude from 210 to $671 \mathrm{~m}$ (Table 1). The boreal forest is characterized by cold winter temperatures and short vegetation periods. Over the last 30 years, the average annual minimum temperature for this region was $-18.4^{\circ} \mathrm{C}$ and average annual maximum temperature was $19.3^{\circ} \mathrm{C}$. Average annual precipitation varied from 920 to $1,187 \mathrm{~mm}$ in the studied stands (Environment Canada 2008). Average age of the studied stands at time of thinning varied from 47 to 82 years. Other than $\mathrm{CT}$, no silvicultural treatment had been applied. Basal area at thinning year ranged between 17 and $50 \mathrm{~m}^{2} /$ ha (Table 1). The herbaceous and moss layers were composed of mainly Pleurozium schreberi (Brid.) Mitt., Polytrichum sp., Ptilium crista-castrensis (Hedw.) De Not., Ledum groenlandicum Oeder, Vaccinium angustifolium Ait. and Kalmia angustifolia L.

\subsection{Sampling}

A $20 \times 20$-m quadrat comprising at least 35 black spruce trees (diameter at breast height $>9 \mathrm{~cm}$ ) was randomly selected in each stand. Total tree height $(H)$, diameter at breast height (Dbh), diameter at the stump (Dsh) and stem height at the lowest living branch were measured for each tree in the quadrat. Site quality was estimated using dominant tree height and production tables (Pothier and Savard 1998; Table 1). Six black spruce trees in each thinned stand and three in each control stand were randomly selected and felled, for a total of 72 trees harvested for stem analysis (one 


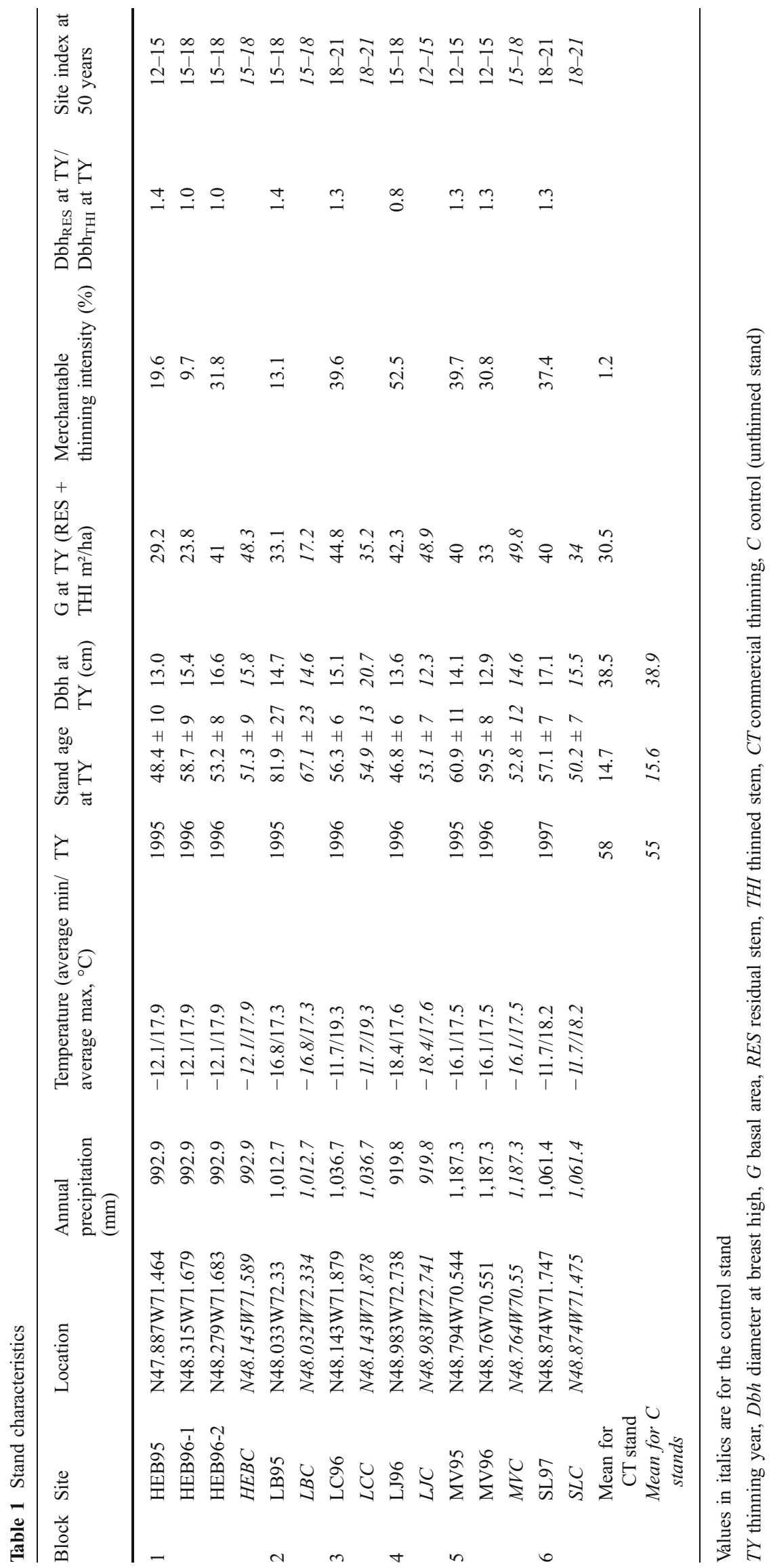


tree was excluded due to handling errors in the laboratory). Stems were cut at every metre, starting at ground level and moving up to the fourth metre, to collect 50-cm-long bolts for mechanical analysis and disks for density analysis.

Disks for density analysis were cut to yield $1.57-\mathrm{mm}$-thick (longitudinal) $\times 5$-mm (tangential) samples in a north-south direction along the pith using a specially designed pneumatic twin-blade saw (FPInnovations, Forintek Division). Sawn strips were extracted with a cyclohexane/ethanol $(2: 1)$ solution for $24 \mathrm{~h}$ and then with hot water for another $24 \mathrm{~h}$ to remove extractives. After extraction, strips were air-dried under restraint to prevent warping.

From the sampled bolts, 10 - $\mathrm{mm}$ (radial) $\times 10$ - $\mathrm{mm}$ (tangential) $\times 150$-mm (longitudinal) specimens from bark to pith were processed along both northern and southern radial directions. Specimen dimensions were defined so that the outermost samples contained mainly tree rings formed after $\mathrm{CT}$ and inner samples had tree rings formed before CT. Defectfree specimens were then dried under restraint from green to $12 \%$ moisture content in a conditioning room $\left(20^{\circ} \mathrm{C}, 65 \%\right.$ HR) and selected for bending tests (see Alteyrac et al. 2006 for a detailed description). These samples were used to test MOE before and after CT.

\subsection{Sample analyses}

Strips were scanned by X-ray densitometry in air-dry conditions. To accommodate a logistic change, densitometry tests were conducted at FPInnovations, Forintek Division., Quebec City, and at UQAT, Rouyn-Noranda, Canada. The same conditions (sample size, preparation and relative humidity) were imposed. However, because X-ray densitometry is a relative measure, density values may vary with the measuring instrument. Reference samples were tested with both densitometers to evaluate the method and verify the compatibility of the results. Moreover, samples from controls and associated thinned sites were measured with the same instrument. X-ray densitometry provided the radial patterns of several properties, including ring width (RW), early-wood width (EWW), late-wood width (LWW), ring density (RD), maximum ring density (MaxRD), minimum ring density (MinRD), early-wood density (EWD) and late-wood density (LWD). Mean annual RD was calculated for 10 years before and after thinning. To determine early-wood and latewood characteristics separately, it is necessary to define the position of the early-wood/latewood transition within the growth ring. Since the transition from early-wood to latewood occurs gradually in black spruce, this boundary was defined as the inflexion point of the intra-ring density profile (Koubaa et al. 2002). The correlation between measured and modelled values by this method exceeded 0.99 for all analysed rings, indicating the power of the model to predict all estimated parameters (Koubaa et al. 2002).
Bending tests were performed at UQAC, Chicoutimi, Canada, according to ASTM D-143 standard test methods for small clear specimens (ASTM 2007). Specimens were placed with growth rings horizontal and with a span of $110 \mathrm{~mm}$. The MOE (stiffness) was evaluated using an MTS-Alliance RT/100 material testing system.

\subsection{Statistical analyses}

Ring characteristics (RW, EWW, LWW and RD), average $\mathrm{RD}$ and MOE variations following CT were examined. In order to reduce environmental and thinning characteristics effects on response variation, we defined a randomized block design (Thysell and Carey 2001; Mäkinen and Isomäki 2004). Each thinning site (9) was matched with a control site (with similar characteristics) to form a block. In two instances, however, the same control stand was used for comparison with more than one nearby thinned stand. Data were compiled by multifactor analysis of variance (ANOVA) using restricted maximum likelihood estimation, the method of variance component estimation suggested for multifactor unbalanced designs (Searle 1992; Quinn and Keough 2002). Block designs included factorial experiment and combination between factors: thinning (two levels: thinned (CT) and unthinned (C)) and time (20 levels: years; and two levels: before and after) in the first part of the paper and height (four levels), thinning and time in the last part. Block was a random effect factor, whereas thinning, time and height were fixed effects. All statistical tests were performed using JMP software (SAS Institute Inc., Cary, $\mathrm{NC})$ at the $95 \%$ confidence level.

\section{Results}

At thinning year, thinned stands had a mean age of 58 years and unthinned 55 years (Table 1). Based on the initial basal area, merchantable thinning intensity varied from $9.7 \%$ to $52.5 \%$ across stands, classified as light to heavy thinning. Moreover, based on the Dbh ratio of residual and thinned stems at thinning year $\left(\mathrm{Dbh}_{\mathrm{RES}}\right.$ at $\mathrm{TY} / \mathrm{Dbh}_{\mathrm{THI}}$ at $\left.\mathrm{TY}\right)$, different $\mathrm{CT}$ types can be identified. When this ratio is $<1$, dominant trees are released to accelerate residual tree growth, which is classed as CT from above. When the ratio is $>1$, suppressed trees are released to stimulate the dominant storey, which is classed as CT from below (Table 1).

\subsection{Growth variation}

During the 20-year period studied (including the thinning year), RW varied from 0.03 to $2.6 \mathrm{~mm}$, with a mean of $0.58 \mathrm{~mm}$, for wood from control stands and from 0.03 to $2.6 \mathrm{~mm}$, with a mean of $0.6 \mathrm{~mm}$, for wood from thinned stands (Fig. 1a). 
RW varied from $0.57 \mathrm{~mm}$ before thinning to $0.62 \mathrm{~mm}$ after thinning for thinned stands and from $0.6 \mathrm{~mm}$ before the thinning year to $0.57 \mathrm{~mm}$ after thinning for the control stands (Fig. 1a). A 12\% increase in RW was observed for thinned stands, whereas a $2 \%$ decrease in RW was observed for control stands (Table 2). Statistical analysis revealed a significant influence of thinning on $\mathrm{RW}$ variation over time ( $p=0.0003$ for interaction time $\times$ thinning, Table 3).

EWW for thinned stands varied from $0.39 \mathrm{~mm}$ before thinning to $0.43 \mathrm{~mm}$ after thinning (Fig. 1b), or a $5 \%$ increase in EW proportion (Table 2). For control stands, EWW varied from $0.41 \mathrm{~mm}$ before thinning year to $0.38 \mathrm{~mm}$ after, or a $4 \%$ decrease in $\mathrm{EW}$ proportion (Fig. 1b and Table 2). EWW followed the same pattern as RW over time (Fig. 1b), and a significant influence of interaction time $\times$ thinning on EWW was noted $(p=0.0019$ for interaction time $\times$ thinning, Table 3 ). In contrast, LWW varied from an average of $0.21 \mathrm{~mm}$ before thinning to $0.22 \mathrm{~mm}$ after thinning for thinned stands, or a slight $1 \%$ increase in LW proportion (Table 2). LWW in control stands varied from $0.21 \mathrm{~mm}$ before thinning year to $0.23 \mathrm{~mm}$ after thinning year, or a $15 \%$ increase in LW proportion. Despite the very small difference between thinned and control stands (Fig. 1c), thinning significantly influenced LWW (Table 3).

\subsection{Ring density variation}

Before thinning, RD of thinned stands was about $504 \mathrm{~kg} / \mathrm{m}^{3}$, decreasing thereafter by about $2 \%$ to approximately $493 \mathrm{~kg} / \mathrm{m}^{3}$. RD for control stands varied from 472 to $471 \mathrm{~kg} / \mathrm{m}^{3}$ (Fig. 2a and Table 2). Before thinning, RD for thinned stands was higher than the annual RD for control stands and decreased after thinning year (time=0, Fig. 2a). The third year after thinning, RD for thinned stands was lower than $\mathrm{RD}$ for controls and continued decreasing thereafter. However, no significant difference was found over time due to thinning ( $p=0.2749$ for interaction time $\times$ thinning, Table 3). Despite a decrease in average RD after thinning for thinned stands (Fig. 2b), no significant variation due to thinning was noted $(p=0.5122$ for interaction time $\times$ thinning, Table 3 ).

\subsection{MOE variation with thinning}

MOE for wood from thinned stands varied from 9.16 to $12.14 \mathrm{GPa}$, with a mean of $10.53 \mathrm{GPa}$, and MOE for wood from control stands varied from 10.53 to $11.16 \mathrm{GPa}$, with a mean of $9.63 \mathrm{GPa}$ (Fig. 3). Figure 3 shows increased MOE for both thinned and control stands after thinning year. No significant variation due to thinning over time $(p=0.2235$ for interaction time $\times$ thinning, Table 3 ) was seen.

\subsection{Stem height influence on MOE and average RD}

Figure 4 shows a decrease in average $\mathrm{RD}$ with increasing stem height for both thinned and control stands $(p>0.0001$ for height, Table 4). Average RD varied from $490 \mathrm{~kg} / \mathrm{m}^{3}$ at the bottom of the log to $463 \mathrm{~kg} / \mathrm{m}^{3}$ in the upper part of the $\log$ (Fig. 4a, b). However, thinning did not influence average $\mathrm{RD}$ up the stem $(p=0.94122$ for the interaction thinning $\times$ height $\times$ time). On the contrary, a slight increase in MOE with increasing tree height for both thinned and control stands is seen in Fig. 4c, d. MOE varied from $9.81 \mathrm{GPa}$ at the bottom of the log to $10.33 \mathrm{GPa}$ in the upper part of the log, and Table 4 shows significant differences in MOE between thinned and control stands.

\section{Discussion}

\subsection{Variation in wood characteristics due to thinning}

CT significantly increased RW, EWW and LWW (Table 3). Moreover, EW proportion increased at the expense of LW proportion (Table 2) after CT in thinned stands. Because silvicultural treatments such as thinning are used mainly to increase growth rate, many studies have addressed the impact of silvicultural treatments on tree growth (Yang et al. 1988; Yang and Hazenberg 1994; Tong and Zhang 2005) and the influence of growth rate on wood anatomical features. A recent study demonstrated that CT led to increased radial growth at the stem base in naturally regenerated black spruce stands (Vincent et al. 2009b). Koga et al. (2002) showed that in balsam fir stands, the annual radial growth response to precommercial thinning (PCT) was limited to EWW, whereas LWW showed little response. According to these authors, lightly thinned and control plots had comparable EWW and latewood percentage. In our case, CT influenced both EWW and LWW, with a more pronounced increase in EWW.

Given the decrease in LW proportion after CT, a decrease in RD would be expected. However, despite a slight decrease in RD after the thinning year (Fig. 2), this variation was not statistically significant (Table 3). No clear relationship between wood density and growth rate was found. Zhang et al. (1996) and Zobel and Van Buijtenen (1989) observed that although a negative relationship generally exists between wood density and growth rate in conifer species, there were many exceptions, and a nonsignificant or even a weak positive relationship between wood density and growth rate can be found in some families. Koubaa et al. (2000) reported a significant negative relationship between wood density and growth rate in juvenile black spruce only. In mature wood, this relationship was no longer significant. In jack pine (Pinus banksiana 

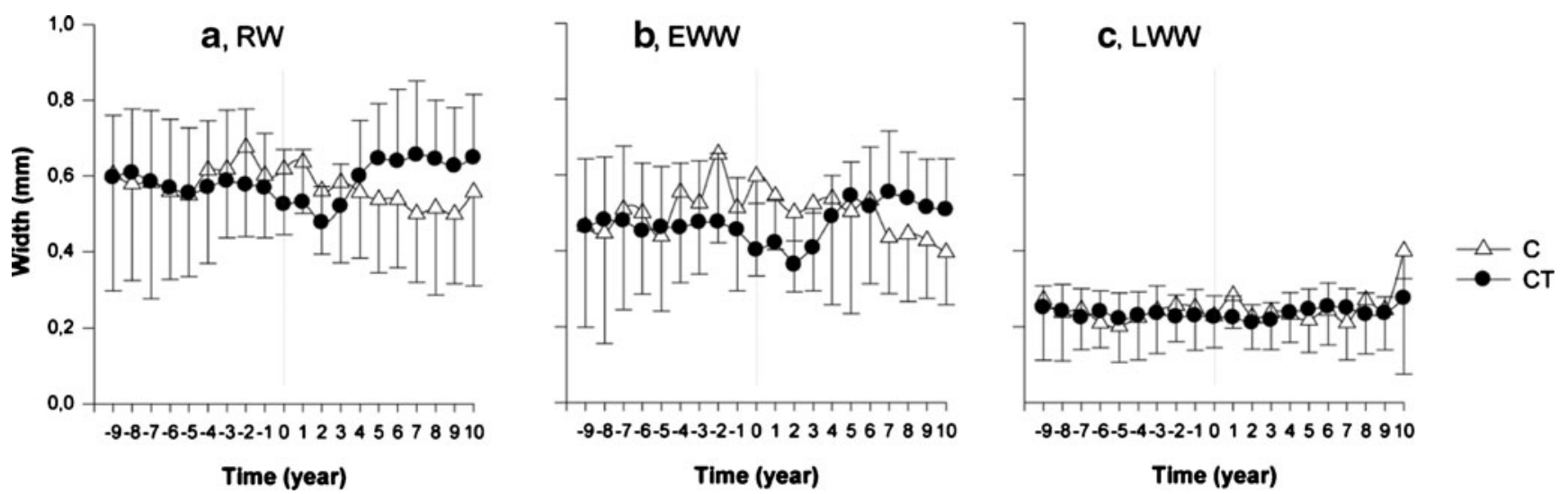

Fig. 1 Change before and after thinning year (time $=0)$ in ring width $(R W$, millimetres) $(\mathbf{a})$, early-wood width $(E W W$, millimetres) $(\mathbf{b})$ and latewood width ( $L W W$, millimetres) (c) for both thinned $(C T$, black circle) and control $(C$, white triangle) stands

Lamb.) and balsam fir (Abies balsamea L.), Barbour et al. (1994) and Kang et al. (2004) observed a reduction in wood density after thinning and with increasing initial spacing. Bendtsen (1978) found negligible effects of accelerated growth on wood properties compared with differences in the properties of mature and juvenile wood. The same result was obtained recently in black spruce stands by Tong et al. (2009) who found no significant variation in average ring density between control and two PCT intensities. Therefore, thinning intensity may have varying influence on growth ring features. Indeed, in terms of wood anatomy, ring growth increment may be insufficient to lead to decreased RD. This implies that increased growth rate is not necessarily linked to decreased wood mechanical properties. Moreover, external factors may also explain the variable results on mechanical properties. For example, St-Germain and Krause (2008) demonstrated that wood growth features such as RW, EWW and LWW decreased with latitude. The age of the studied trees and the length of the studied period also contributed to explain the variation in measured RD. Koubaa et al. (2000) demonstrated a decreasing correlation between RW and RD with increasing age.

Table 2 Ring characteristics and MOE variation by stand

\begin{tabular}{|c|c|c|c|c|c|}
\hline Site & $\begin{array}{l}\mathrm{RW} \\
\text { variation (\%) }\end{array}$ & $\begin{array}{l}\text { Variation in EWW } \\
\text { proportion }(\%)\end{array}$ & $\begin{array}{l}\text { Variation in LWW } \\
\text { proportion }(\%)\end{array}$ & $\begin{array}{l}\mathrm{RD} \\
\text { variation (\%) }\end{array}$ & $\begin{array}{l}\text { MOE } \\
\text { variation (\%) }\end{array}$ \\
\hline HEB95 & 97.6 & 101.9 & 95.6 & 98.6 & 115.8 \\
\hline HEB96-1 & 113.0 & 90.0 & 112.0 & 94.6 & 107.1 \\
\hline HEB96-2 & 105.7 & 99.8 & 96.0 & 102.3 & 106.3 \\
\hline HEBC & 96.8 & 96.7 & 105.2 & 101.6 & 103.8 \\
\hline LB95 & 109.0 & 101.4 & 90.6 & 95.2 & 110.8 \\
\hline $\mathrm{LBC}$ & 91.4 & 94.1 & 115.3 & 96.5 & 94.9 \\
\hline LC96 & 96.9 & 94.9 & 107.8 & 97.3 & 101.7 \\
\hline $\mathrm{LCC}$ & 123.1 & 94.4 & 95.4 & 97.7 & 108.2 \\
\hline LJ96 & 110.3 & 99.4 & 103.0 & 100.1 & 116.2 \\
\hline LJC & 86.7 & 93.3 & 115.7 & 98.0 & 108.0 \\
\hline MV95 & 99.5 & 199.2 & 125.8 & 97.0 & 112.6 \\
\hline MV96 & 175.6 & 54.2 & 62.3 & 98.2 & 113.6 \\
\hline MVC & 79.3 & 110.6 & 114.8 & 102.4 & 94.0 \\
\hline SL97 & 97.8 & 105.4 & 101.2 & 95.0 & 118.7 \\
\hline SLC & 107.4 & 86.6 & 148.5 & 100.6 & 107.7 \\
\hline Mean for CT stand & 111.7 & 105.1 & 99.3 & 97.6 & 111.4 \\
\hline Mean for C stands & 97.5 & 95.9 & 115.8 & 99.5 & 102.8 \\
\hline
\end{tabular}

The percentage corresponds to the ratio of mean values by stand of ring characteristics and MOE for the 10 years preceding thinning year on the mean values by stand of ring characteristics and MOE ring characteristics for the 10 years following thinning year

$R W$ ring width, $E W W$ early-wood width, $L W W$ late-wood width, $R D$ ring density, $M O E$ modulus of elasticity, $C T$ commercial thinning, $C$ controls 
Table 3 ANOVA for thinning and temporal effects on RW, EWW, LWW, RD, average RD and MOE

\begin{tabular}{llcccc}
\hline Test & Source & $D F$ & DFDen & $F$ ratio & Prob. $>F$ \\
\hline Ln(RW) & Thinning & 1 & 4.997 & 0.0196 & 0.8942 \\
& Time & 19 & 180.2 & 1.1424 & 0.3128 \\
Ln(EWW) & Time $\times$ thinning & 19 & 180.2 & 2.6921 & $0.0003^{\mathrm{a}}$ \\
& Thinning & 1 & 4.983 & 0.0187 & 0.8967 \\
& Time & 19 & 292 & 0.7551 & 0.7593 \\
Ln(LWW) & Time $\times$ thinning & 19 & 292 & 2.2898 & $0.0019^{\mathrm{a}}$ \\
& Thinning & 1 & 4.96 & 0.0050 & 0.9466 \\
Ln(RD) & Time & 19 & 232.2 & 3.1414 & $<.0001^{\mathrm{a}}$ \\
& Time $\times$ thinning & 19 & 232.2 & 2.0862 & $0.0061^{\mathrm{a}}$ \\
& Thinning & 1 & 4.963 & 2.9606 & 0.1464 \\
Ln(Average RD) & Time & 19 & 324.6 & 3.0524 & $<0.0001^{\mathrm{a}}$ \\
& Time $\times$ thinning & 19 & 324.6 & 1.1771 & 0.2749 \\
& Thinning & 1 & 4.649 & 3.1472 & 0.1407 \\
MOE & Time & 1 & 40.51 & 1.5646 & 0.2182 \\
& Time $\times$ thinning & 1 & 40.51 & 0.4372 & 0.5122 \\
& Thinning & 1 & 4.736 & 18.5509 & $0.0087^{\mathrm{a}}$ \\
& Time & 1 & 7.029 & 16.7981 & $0.0045^{\mathrm{a}}$ \\
& Time $\times$ thinning & 1 & 7.029 & 1.7824 & 0.2235 \\
\hline
\end{tabular}

Table 1 presents between- and within-block differences in terms of thinning influence. Specifically, block LB is questionable because LBC had a $G_{\mathrm{TY}}$ nearly half that of LB95 (Table 1). It is therefore arguable that these two stands were not comparable. However, a previous study on the same material demonstrated that both LBC and LB95 were affected by outbreaks of spruce budworm (Choristoneura fumiferana (Clemens)) in the late 1970s (Morin et al. 2000; Vincent et al. 2009b). Comparing radial growth over time, these outbreaks appear to have affected LBC longer (by about 2 years) than LB95 (data not shown). Moreover, radial growth for LBC after the outbreaks resumed faster and was greater than for LB95 (Vincent et al. 2009b). These variations in tree growth may influence changes in RD and affect the results. In fact, most studies in this area show a predominance of between- stand, inter-tree and intra-tree variability in silvicultural impacts on mechanical wood properties. Dutilleul et al. (1998) noted that the correlation between RW, RD and mean tracheid length may be affected by heavy thinning, which would partly explain the contradictory results reported in the literature.

No significant variation in MOE due to thinning was observed in this study (Table 3). MOE differed between thinned and control stands and increased after thinning year in both thinned and control stands. However, average $\mathrm{RD}$ tended to decrease after thinning, with a slight increase in MOE after thinning. Although variations in MOE due to different initial spacings were observed, the influence of $\mathrm{CT}$ on MOE was more ambiguous. Zhang et al. (2002) studied lumber strength variation following three different initial spacings of black spruce plantations.
Fig. 2 Change before and after thinning year $($ time $=0)$ in ring density $(R D$, kilograms per cubic metre) (a) and average ring density (Average RD, kilograms per cubic metre) (b) for both thinned (CT, black circle) and control $(C$, white triangle $)$ stands
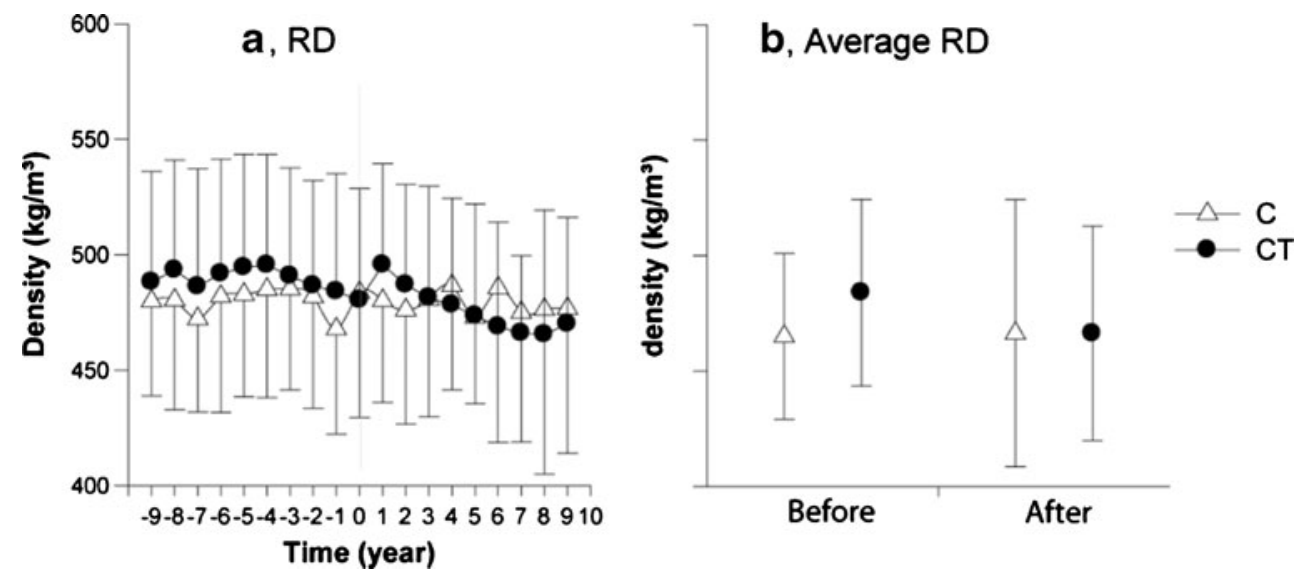


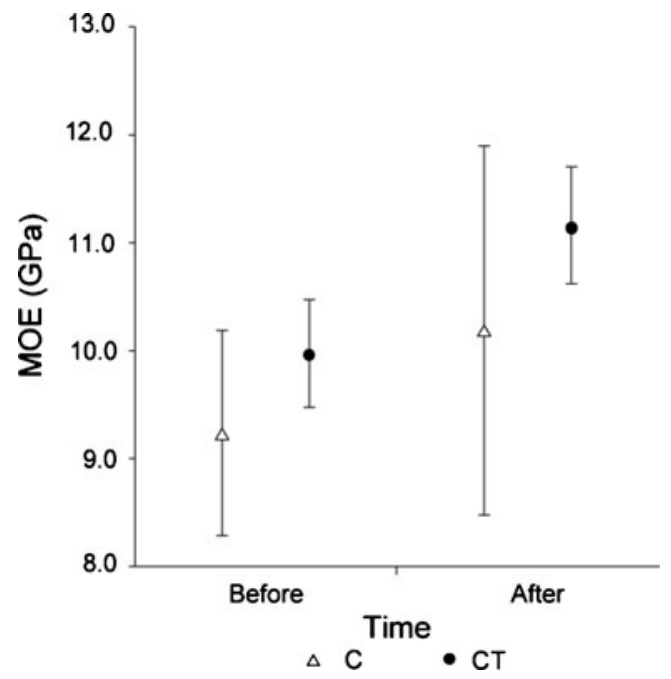

Fig. 3 Variation in modulus of elasticity ( $M O E$, gigapascals) for both thinned $(C T$, black circle) and control $(C$, white triangle $)$ stands

Compared with natural stand lumber currently processed in eastern Canada, the stiffness of plantation-grown black spruce lumber was $28.9 \%$ lower on average. As a result, a high percentage of the plantation-grown lumber did not meet the bending design values (Zhang et al. 2002). In contrast, $\mathrm{CT}$ in plantations increased radial growth and did not lead to decreased MOE. From a wood supply standpoint, bigger logs from thinned natural stands would not be expected to have the lower mechanical properties associated with plantation logs of similar dimensions.

The larger variation of MOE from the unthinned control stands compared with thinned stands may be of interest for further studies to discuss because it may disclose a more heterogeneous wood material in the unthinned stand. Alteyrac et al. (2006) demonstrated that ring density had lower contribution in predicting MOE than the modulus of rupture and that it was negatively correlated to microfibril angle. According to these authors, this relation between MOE and microfibril angle is not dependant on radial growth rate. However, Herman et al. (1999) demonstrated that intra- and inter-ring trajectories of microfibril angle in Norway spruce were affected by growth rate. This relation between MOE and microfibril angle may be the cause of the variations observed between material from thinned and unthinned stands, but it requires further study in order to better explain these observations.
Fig. 4 a Change along the first $4 \mathrm{~m}$ of stem in average ring density (Average $R D$ ) for thinned stands. b Average RD for control stands. c, d Modulus of elasticity $(M O E)$ for thinned stands and control stands before (black square) and after (white square) thinning year
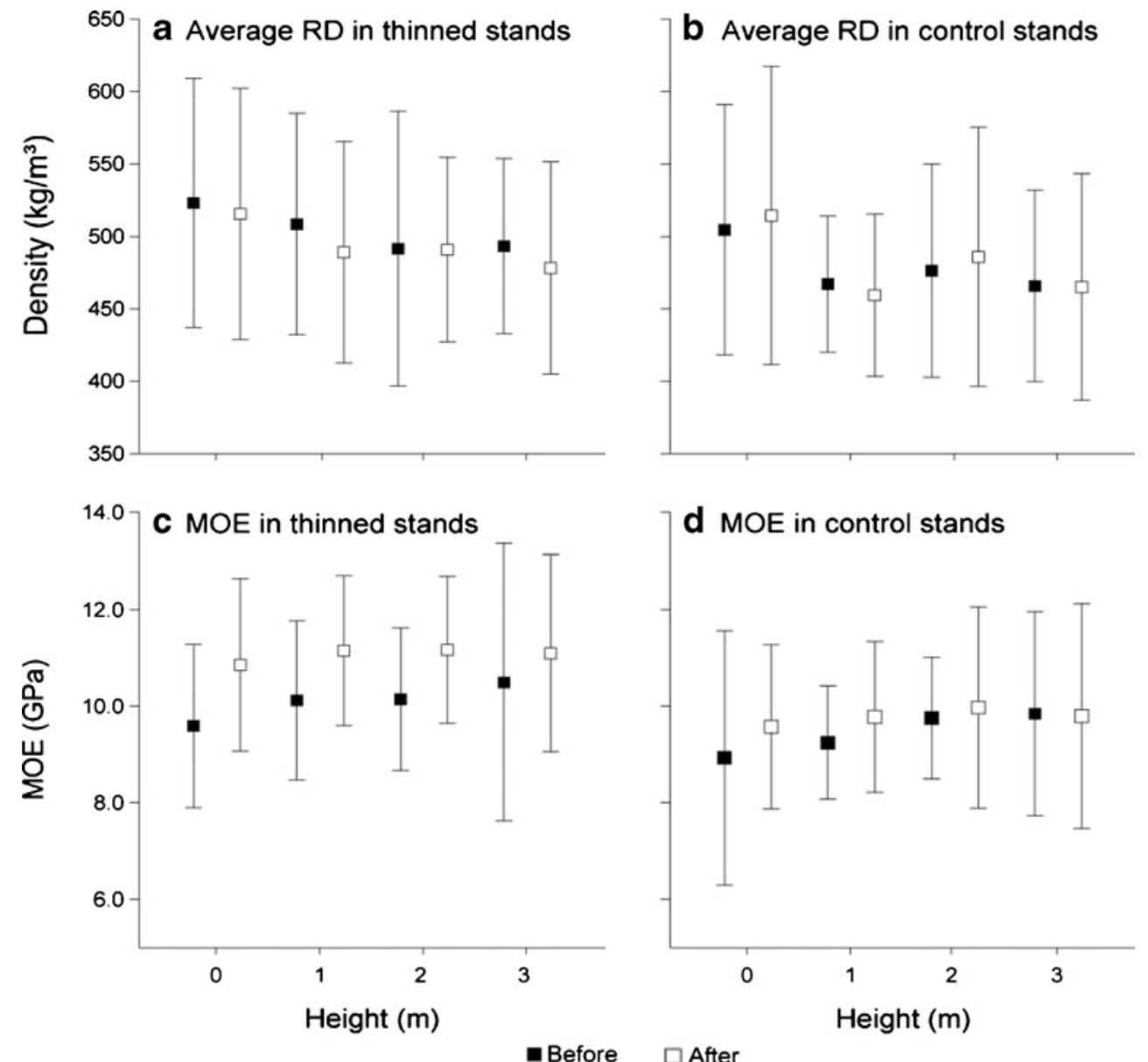
Table 4 Effect from ANOVA for average $\mathrm{RD}$ and $\mathrm{MOE}$ before and after thinning: analysis with tree height
${ }^{\text {a }}$ Significant at the $95 \%$ confidence level

\begin{tabular}{|c|c|c|c|c|c|}
\hline Test & Source & $D F$ & DFDen & $F$ ratio & Prob. $>F$ \\
\hline \multirow[t]{7}{*}{ Ln(Average RD) } & Height & 3 & 25.32 & 10.7301 & $<0.0001^{\mathrm{a}}$ \\
\hline & Thinning & 1 & 57.21 & 3.2067 & 0.0786 \\
\hline & Thinning $\times$ height & 3 & 42.07 & 0.6460 & 0.5899 \\
\hline & Time & 1 & 171.4 & 0.2792 & 0.5979 \\
\hline & Time $\times$ thinning & 1 & 171.4 & 0.8895 & 0.3469 \\
\hline & Time $\times$ height & 3 & 170.6 & 0.2030 & 0.8942 \\
\hline & Time $\times$ thinning $\times$ height & 3 & 170.6 & 0.1315 & 0.9412 \\
\hline \multirow[t]{7}{*}{ MOE } & Height & 3 & 21.36 & 1.0684 & 0.3834 \\
\hline & Thinning & 1 & 25.39 & 19.5306 & $0.0002^{\mathrm{a}}$ \\
\hline & Thinning $\times$ height & 3 & 23.48 & 0.6229 & 0.6073 \\
\hline & Time & 1 & 38.81 & 26.7639 & $<0.0001^{\mathrm{a}}$ \\
\hline & Tiime $\times$ height & 1 & 38.81 & 2.7163 & 0.1074 \\
\hline & Time $\times$ thinning & 3 & 38.72 & 2.1729 & 0.1068 \\
\hline & Time $\times$ thinning $\times$ height & 3 & 38.72 & 0.7231 & 0.5443 \\
\hline
\end{tabular}

\subsection{Variation in wood characteristics with tree height}

$\mathrm{RD}$ and MOE varied significantly with tree height, but no significant effect of thinning with tree height was observed. It was noted previously that logs cut from different positions in the tree had different wood and fibre characteristics (Larson et al. 2004; Tong et al. 2009). Moreover, previous studies have revealed variations in growth rate with $\log$ position in the stem after silvicultural treatment (Koga et al. 2002; Vincent et al. 2009a). However, according to Alteyrac et al. (2005), sampling height appeared to have a larger impact on density variation than growth rate on RD. Koga and Zhang (2004) observed a negative correlation between RD and RW in balsam fir, which was significant in the butt $\log$ but decreased to insignificance at and above a height of $3 \mathrm{~m}$, and other authors noticed the ring density decreased up to the first $5 \mathrm{~m}$ (Evans et al. 2000; Spicer and Gartner 2001). The present study seems in agreement with these authors (Table 4), but more work on data along the entire stem is needed to confirm these findings. Moreover, the rapid decrease in cambial age with tree height may explain changes in ring density up the stem.

Regarding MOE variation with log position, Tong et al. (2009) found no significant correlation between lumber MOE and log position in precommercially thinned black spruce plantations when all log positions were considered. However, when butt logs (0-2.5 m) were excluded, MOE decreased steadily with increasing log height. In the present paper, butt logs were included in the analysis, which may explain the unexpected observations: the differing MOE within butt logs may be attributed to the presence of various stages of compression wood (Larson et al. 2004; Tong et al. 2009). To our knowledge, no study has addressed the role of the root system close to the stump and its influence on wood properties at the stem base. Nevertheless, it is evident that root fibre and stem orientation differ and that the transition between root and stem is not clearly defined. The increasing proportion of less mature wood up to the stem may also explain these results.

\section{Conclusion}

The main conclusion of this study is that RW significantly increased after CT, but no significant variation in $\mathrm{RD}$ due to thinning was observed. Moreover, despite a slight increase observed for thinned stands, MOE did not vary significantly after thinning. These results support the argument for commercial thinning in natural black spruce stands in the boreal forest without concerns about wood quality after thinning. Moreover, the high density associated with lumber stiffness properties of the studied black spruce makes it a good candidate for lumber end uses. However, the large variation in MOE needs to be taken into account.

Finally, this study showed that mechanical wood properties vary up the stem and that this variation is greater than the variation due to thinning. These results are of interest, given the increasing need to develop optimal log allocation strategies. As the forest industry shifts towards value-added end uses, it has become important to allocate logs to the best uses to maximize the value of the resource and ensure end-product quality.

Further studies are needed to enhance our knowledge in this area, notably the influence of different wood mechanical properties on MSR lumber yield, which is usually used for saw $\log$ classification. 
Acknowledgements The authors would like to thank Mireille Boulianne and Audrey Lemay for lab and field assistance, Jean Guy Girard for cutting help, Véronique Leclerc and Denis Walsh for statistical advice and helpful discussions, and Maxime Blackburn, Charles-Augustin Déry-Bouchard, Boris Luszcynski, Emilie Pamerleau-Couture, Pierre-Yves Plourde, Germain Savard and MarcAndré Valiquette for field assistance. The authors also thank Francis Tanguay and Tony Zhang's team and Ahmed Koubaa's team for X-ray densitometer assistance. Funding was provided by FQRNT (2007-FO118063 ) through a research grant. The Consortium de Recherche sur la Forêt Boréale Commerciale provided additional support.

\section{References}

Alteyrac J, Zhang SY, Cloutier A, Ruel JC (2005) Influence of stand density on ring width and wood density at different sampling heights in black spruce (Picea mariana (Mill.) BSP). Wood Fiber Sci 37:83-94

Alteyrac J, Cloutier A, Ung C-H, Zhang SY (2006) Mechanical properties in relation to selected wood characteristics of black spruce. Wood Fiber Sci 38:229-237

ASTM (2007) D 143-94 (Reapproved 2007) —Standard test methods for small clear specimens of timber. In: ASTM (ed) Wood ASTM. ASTM International, Philadelphia, p 32

Barbour RJ, Fayle DCF, Chauret G, Cook J, Karsh MB, Ran SK (1994) Breast-height relative density and radial growth in mature jack pine (Pinus banksiana) for 38 years after thinning. Can J For Res 24:2439-2447

Bendtsen BA (1978) Properties of wood from improved and intensively managed trees. Forest Prod J 28:61-72

Briggs DG, Fight RD (1992) Assessing the effects of silvicultural practices on product quality and value of coast Douglas-fir trees. Forest Prod J 42:40-46

Cameron AD (2002) Importance of early thinning in the development of long-term stand stability and improved log quality: a review. Forestry $75: 25-35$

Castéra P, Faye C, El Ouadrani A (1996) Prevision of the bending strength of timber with a multivariate statistical approach. Ann For Sci 53:885-898

Dixon RK, Brown S, Houghton RA, Solomon AM, Trexler MC, Wisniewski J (1994) Carbon pools and flux of global forest ecosystems. Science 263:185-190

Downes GM, Wimmer R, Evans R (2002) Understanding wood formation: gains to commercial forestry through tree-ring research. Dendrochronologia 20:37-51

Dutilleul P, Herman M, Avella-Shaw T (1998) Growth rate effects on correlations among ring width, wood density, and mean tracheid length in Norway spruce (Picea abies). Can J For Res 28:56-68

Echols RM (1972) Products suitability of wood determined by density gradients across growth rings. In: Research Note PSW-273. USDA Forest Service, Berkeley, CA

Environment Canada (2008) Canadian daily climate data (CDCD). In: National Climate Data and Information Archive

Evans R, Stringer S, Kibblewhite RP (2000) Variation of microfibril angle, density and fibre orientation in 29 Eucalyptus nitens trees. Appita J 53:450-457

Herman M, Dutilleul P, Avella-Shaw T (1999) Growth rate effects on intra-ring and inter-ring trajectories of microfibril angle in Norway spruce (Picea abies). IAWA J 20:3-21

Kang KY, Zhang SY, Mansfield SD (2004) The effects of initial spacing on wood density, fibre and pulp properties in jack pine (Pinus banksiana Lamb.). Holzforschung 58:455-463

Kellogg RM, Warren WG (1984) Evaluating Western hemlock stem characteristics in terms of lumber value. Wood Fiber Sci 16:583-597
Koga S, Zhang SY (2002) Relationships between wood density and annual growth rate components in balsam fir (Abies balsamea). Wood Fiber Sci 34:146-157

Koga S, Zhang SY (2004) Inter-tree and intra-tree variations in ring width and wood density components in balsam fir (Abies balsamea). Wood Sci Technol 38:149-162

Koga S, Zhang SY, Bégin J (2002) Effects of precommercial thinning on annual radial growth and wood density in balsam fir (Abies balsamea). Wood Fiber Sci 34:625-642

Koubaa A, Zhang SY, Isabel N, Beaulieu J (2000) Phenotypic correlations between juvenile-mature wood density and growth in black spruce. Wood Fiber Sci 32:61-71

Koubaa A, Zhang SYT, Makni S (2002) Defining the transition from early wood to late wood in black spruce based on intra-ring wood density profiles from X-ray densitometry. Ann For Sci 59:511-518

Larson D, Mirth R, Wolfe R (2004) Evaluation of small-diameter ponderosa pine logs in bending. Forest Prod J 54:52-58

Mäkinen H, Isomäki A (2004) Thinning intensity and long-term changes in increment and stem form of Norway spruce trees. For Ecol Manag 201:295-309

Melillo JM, McGuire AD, Kicklighter DW, Moore B, Vorosmarty CJ, Schloss AL (1993) Global climate-change and terrestrial net primary production. Nature 363:234-240

Morin H, Krause C, Jardon Y, Parent S, Deslauriers A, Gionest F, Simard I, Levasseur V, Desjardins O (2000) Dynamique spatiotemporelle des épidémies de la tordeuse des bourgeons de l'épinette (tbe) dans la zone boréale de l'est de l'Amérique du Nord (Ont., Qué., T.N. et N.B.). In: forêts Rslgdd (ed) Project report 2000-38. Réseau sur la gestion durable des forêts, Project report 2000-38, Final project report, Ontario, p. 30 p

Parent B, Fortin C (2008) Ressources et Industries ForestièresPortrait Statistique Édition 2008. In: MRNF (ed) Ministère des Ressources Naturelles et de la Faune-Direction du développement de l'industrie des produits forestiers, Québec, p 513

Petrás R (2002) Age and diameter classes or growth stages as criteria for the implementation of thinning. J For Sci 48:8-15

Pnevmaticos SM, Corneau Y, Kerr RC (1979) Yield and productivity in processing treelength softwoods in Quebec. Can For Ind 99:37-51

Pothier D (2002) Twenty-year results of precommercial thinning in a balsam fir stand. For Ecol Manag 168:177-186

Pothier D, Savard F (1998) Actualisation des tables de production pour les principales espèces forestières du Québec. Direction des inventaires forestiers, Ministère des Ressources naturelles, Sainte-Foy 1-183

Prégent G (1998) L'éclaircie des plantations In: Québec Gd (ed) Mémoire de recherche forestière no 133. Gouvernement du Québec, Ministère des Ressources Naturelles, Forêt Québec, Direction de la recherche forestière, Sainte-Foy (Québec), p 38

Quinn GP, Keough MJ (2002) Experimental design and data analysis for biologists. Cambridge University Press, Cambridge $537 \mathrm{pp}$

Searle SR (1992) Variance components. Wiley, New York

Shi JL, Riedl B, Deng J, Cloutier A, Zhang SY (2007) Impact of log position in the tree on mechanical and physical properties of black spruce medium-density fibreboard panels. Can J For Res 37:866-873

Spicer R, Gartner BL (2001) The effects of cambial age and position within the stem on specific conductivity in Douglas-fir (Pseudotsuga menziesii) sapwood. Trees Struct Funct 15:222-229

St-Germain J, Krause C (2008) Latitudinal variation in tree ring and wood cell characteristics of Picea mariana acroos the continuous boreal forest in Quebec. Can J For Res 38:1397-1405

Thibodeau L, Raymond P, Camiré C, Munson AD (2000) Impact of precommercial thinning in balsam fir stands on soil nitrogen dynamics, microbial biomass, decomposition, and foliar nutrition. Can J For Res 30:229-238 
Thysell DR, Carey AB (2001) Manipulation of density of Pseudotsuga menziesii canopies: preliminary effects on understory vegetation. Can J For Res Revue Can Recherche Forestiere 31:1513-1525

Tong QJ, Zhang SY (2005) Impact of initial spacing and precommercial thinning on jack pine tree growth and stem quality. Forest Chron 81:418-428

Tong QJ, Fleming RL, Tanguay F, Zhang SY (2009) Wood and lumber properties from unthinned and precommercially thinned black spruce plantations. Wood Fiber Sci 41:168-179

Vincent M, Krause C, Koubaa A (2009a) How does commercial thinning influence profile shape on Picea mariana: a case-study in Québec's boreal forest. UQAC, Québec, p 26

Vincent M, Krause C, Zhang S (2009b) Radial growth response of black spruce roots and stems to commercial thinning in boreal forest. Forestry 82:557-571

Yang KC, Hazenberg G (1994) Impact of spacing on tracheid length, relative density, and growth rate of juvenile wood and mature wood in Picea mariana. Can J For Res 24:996-1007

Yang RC, Wang EIC, Micko MM (1988) Effects of fertilization on wood density and tracheid length of 70-year-old lodge- pole pine in west-central Alberta. Can J For Res 18:954956

Zhang SY, Koubaa A (2009) Les résineux de l'Est du Canada: Écologie forestière, caractéristiques, transformation et usages. In: FPInnovations (ed) Publication spéciale-SP-526E. FPInnovations-Forintekdivision, Québec, pp 1-28

Zhang SY, Simpson D, Morgenstern EK (1996) Variation in the relationship of wood density with growth in 40 black spruce (Picea mariana) families grown in New Brunswick. Wood Fiber Sci 28:91-99

Zhang SY, Chauret G, Ren HQQ, Desjardins R (2002) Impact of initial spacing on plantation black spruce lumber grade yield, bending properties, and MSR yield. Wood Fiber Sci 34:460-475

Zhang T, Chauret G, Duchesne I, Schneider R (2005) Maximizing jack pine value. Fact sheet - knowledge transfert

Zhang SY, Chauret G, Swift E, Duchesne I (2006) Effects of precommercial thinning on tree growth and lumber quality in a jack pine stand in New Brunswick, Canada. Can J For Res 36:945-952

Zobel B, Van Buijtenen J (1989) Wood variation: its causes and control. Springer, Berlin, 363 pp 